\title{
Large lutjanid and serranid fishes in tropical estuaries: Are they adults or juveniles?
}

\author{
Marcus Sheaves* \\ Department of Marine Biology, James Cook University of North Queensland, 4811 Townsville, Australia
}

\begin{abstract}
Two serranid fishes, Epinephelus coioides and E. malabaricus, and 2 lutjanid fishes, Lutjanus argentimaculatus and $L$. russelli, are common in estuaries of northeastern tropical Australia. Reviews of the literature suggest that, at least for E. coioides, E. malabaricus and L. argentimaculatus, both juveniles and adults occur in estuaries. I conducted the present study to determine if estuarine populations of these 4 species did in fact contain adults, or if they were comprised entirely of juveniles. I collected E. coioides, E malabaricus, $L$. russelli and $L$. argentimaculatus from estuaries in northeastern Australia. I compared the size, age and reproductive maturity of fishes from estuaries to fishes of the same species from offshore areas. The estuarine populations of all 4 species seemed to consist entirely of reproductively immature fish. All fish from the estuaries possessed immature gonads, and for both serranids (protogynous hermaphrodites) all were females. Furthermore, all fish from the estuaries were much smaller and younger than the largest fish of the same species from offshore. This implies that estuaries are important juvenile development grounds for these lutjanids and serranids.
\end{abstract}

KEY WORDS: Estuary Juvenile - Nursery ground - Life-cycle $\cdot$ Size $\cdot$ Age $\cdot$ Reproductive maturity

\section{INTRODUCTION}

It is generally considered that estuaries in tropical Indo-Pacific waters are dominated by small fishes, including the juveniles of many species (Blaber 1980, Blaber et al. 1985, 1989, Robertson \& Duke 1987). While a number of studies have considered estuarine fish assemblages in the Indo-Pacific, the biology of individual species has received little attention. This is particularly true of habitat associated predators such as lutjanids and serranids. The structurally complex habitats used extensively by these species (Sheaves 1992) inhibit sampling with seine and gill nets, the gears employed in most studies. In consequence, members of these families have usually been sampled only in low numbers. Despite this, these fish comprised a major part of anglers' catches from an estuary in tropical Australia (Sheaves 1992), and fish trapping data (Sheaves 1992, 1995) suggests that gears which target appropriate habitats may produce quite high catch rates of lutjanids and serranids.

\footnotetext{
•E-mail: marcus.sheaves@jcu.edu.au
}

Recent reviews (Randall \& Ben-Tuvia 1983, Allen 1985, Allen \& Talbot 1985, Randall 1987, Randall et al. 1990) list Lutjanus argentimaculatus and L. russelli as inhabitants of coastal and estuarine waters. These works suggest that within estuaries, L. argentimaculatus occurs as juveniles and sub-adults while L. russelli is present as juveniles only. However, few studies of Indo-Pacific estuarine fishes have reported the reproductive status or life-history stages of these species. Where such classification has been carried out, L. russelli populations have usually been classified as juveniles (Blaber 1986, Blaber \& Milton 1990, Thollot et al. 1990). While most studies that have recorded $L$. argentimaculatus from estuaries have reported the presence of juveniles, a number of studies have also reported the presence of adults (Shine et al. 1973, Blaber 1980, Blaber et al. 1989, Blaber \& Milton 1990, Thollot et al. 1990). While Blaber (1980) stated that 'all reproductively immature fish were classed as juvenile', in most cases the criteria used to evaluate reproductive status are unclear.

The life history of 2 serranids in Indo-Pacific estuaries is also uncertain. Epinephelus coioides and E. mala- 
baricus are both known to inhabit coastal and estuarine waters (Randall \& Ben-Tuvia 1983, Randall et al. 1990). Where life-history stages have been recorded, both juvenile and adult $E$. coioides (recorded as $E$. suillus, a synonym of $E$ coioides; Randall et al. 1990) (Blaber \& Milton 1990) and E. malabaricus (Thollot et al. 1990) have been reported. However, the criteria used for these determinations were not presented. Thus, there is little direct evidence of the reproductive or life-history status of either the 2 lutjanids or these 2 serranids within Indo-Pacific estuaries.

In the present study, I determined the reproductive statuses of Epinephelus coioides, E. malabaricus, Lutjanus argentimaculatus and L. russelli within estuaries in tropical northeastern Australia. Assessment was made in terms of the maturity (macroscopic and histological) and relative size of gonads. I also compared the reproductive statuses and age and size structures of fishes of these 4 species from estuaries to fishes of the same species from offshore waters.

\section{MATERIALS AND METHODS}

Collection of samples. Between October 1990 and November 1994, specimens of Epinephelus coioides, E. malabaricus, Lutjanus argentimaculatus and L. russelli were collected to provide size structure, gonad and otolith samples.

Estuary samples were collected from fish trap catches supplemented by line caught fish, either captured during research or supplied by anglers. Between October 1991 and August 1993, extensive fish trapping was conducted in Cattle, Barramundi and Alligator Creeks (Fig. 1), using 12 Antillean-Z fish traps (1800 mm long, $1100 \mathrm{~mm}$ wide, $600 \mathrm{~mm}$ high, plan area approx. $1.53 \mathrm{~m}^{2}$, volume approx. $0.92 \mathrm{~m}^{3}$ ) with $12.5 \mathrm{~mm}$ square galvanised steel mesh and straight entrance funnels (inner opening $260 \times 150 \mathrm{~mm}$ ). This sampling included estuaries spanning about $145 \mathrm{~km}$ of coast and consisted of 2736 trap sets. Trapping extended over the entire lengths of these creeks which could be navigated in a $3 \mathrm{~m}$ dingy (about $15 \mathrm{~km}$ for Cattle and Barramundi Creeks, and $7.5 \mathrm{~km}$ for Alligator Creek), and occurred once every 3 mo during the study period. The traps used and sampling procedures are described in detail in Sheaves (1995). Line caught fish originated from a large number of estuaries between Hinchinbrook Island (approximately $18^{\circ} 10^{\prime} \mathrm{S}, 146^{\circ} 10^{\prime} \mathrm{E}$ ) and Barramundi Creek $\left(19^{\circ} 25^{\prime} \mathrm{S}, 147^{\circ} 10^{\prime} \mathrm{E}\right)$, a length of coast extending approximately $220 \mathrm{~km}$. In an attempt to ensure that fish of the largest sizes available in estuaries were obtained, all line fishing was aimed at catching large individuals, and pamphlets requesting large fish of the required species were distributed

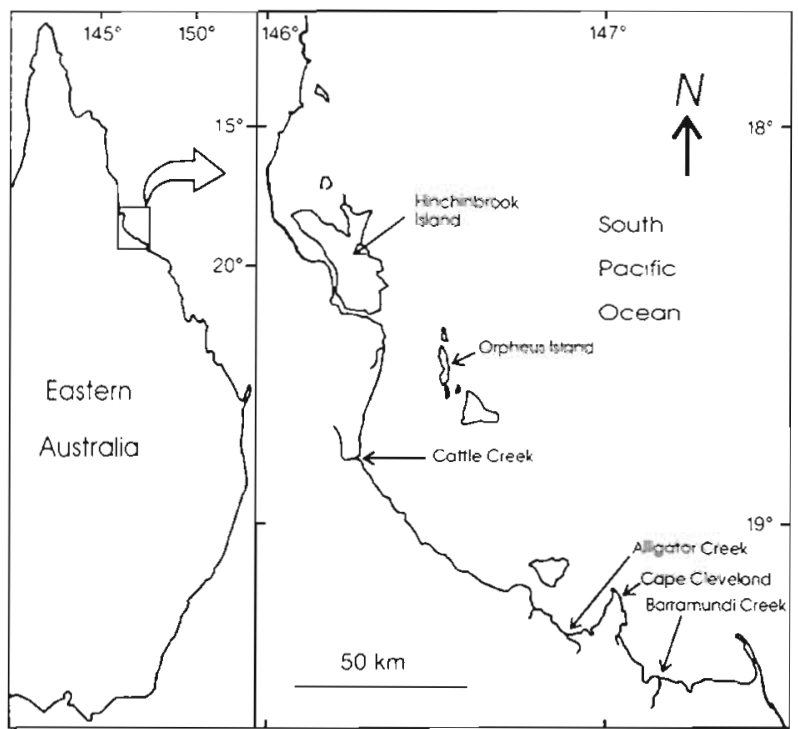

Fig. 1. Sampling sites for the collection of lutjanid and serranid fishes from estuarine and nearshore waters

through angling clubs and displayed in fishing tackle shops. In addition, requests for samples were made directly of anglers encountered in the field.

Samples were also collected from waters offshore of the estuaries studied. Sampling was conducted on offshore reefs around Cape Cleveland (a coastal headland) and Orpheus Island (a near-shore island) (Fig. 1), utilising the same fish traps and trapping methods used for estuary sampling. These samples were supplemented by fish from angler donations, trawl samples from Cleveland Bay (Fig. 1), and fish collected during research trips for other projects.

Determination of reproductive status. Immediately upon capture or receipt of donated samples, fish were placed on ice where they were kept until dissected (less than $12 \mathrm{~h}$ ). Gonads were preserved in FAAC fixative (formaldehyde $4 \%$, acetic acid $5 \%$, calcium chloride $1.3 \%$; McCormick \& Molony 1992). Gonads were weighed within $2 \mathrm{~d}$ of preservation and returned to the fixative where they were stored until histological preparation was carried out (within $1 \mathrm{mo}$ )

Fish were initially classified as females, males or of indeterminate sex from the macroscopic appearance of their gonads. Histological examination was carried out on all gonads greater than approximately $1 \mathrm{~mm}$ diameter. Smaller gonads were not examined histologically as they were difficult to process and it was considered unlikely that they would be sexually mature. In support of this premise, most of the smaller gonads examined contained only oogonia or spermatogonia (precursors of oocytes or spermatozoa respectively) rather than more developed gonadial tissue. 
A section from each of the anterior, central and posterior regions of 1 gonad from each fish was embedded in paraffin wax and transverse sections cut at $6 \mu \mathrm{m}$. The sections were stained with haematoxylin and eosin. The sex of each gonad was determined by microscopic examination and for each female, the stage of the most advanced oocyte was recorded.

Ovarian tissue was staged according to the scheme described by West (1990) as follows: Stage 1, chromatin nucleolar stage; Stage 2, perinucleolar stage; Stage 3, yolk vesicle formation; Stage 4, vitellogenic stage; Stage 5, ripe.

For each male, the most advanced stage of spermatic tissue present was recorded.

Growth from mark-recapture. In conjunction with fish trapping studies in Cattle, Barramundi and Alligator Creeks (Sheaves 1993, 1995, unpubl. data) between 14 October 1991 and 25 August 1993, Epinephelus coioides, E. malabaricus, Lutjanus argentimaculatus over $150 \mathrm{~mm}$ and $L$. russelli over $100 \mathrm{~mm}$ were tagged and released. In addition to fish tagged during fish trapping, fish captured by hook and line were also tagged. All fish were tagged with Hallprint medium T-bar anchor tags. Upon capture and recapture the fork length (FL) of each fish was recorded to the nearest millimetre. To prevent the use of non-independent samples, where fish were recaptured on more than one occasion only data from the longest period at liberty was used in the analysis of growth.

As growth must be zero at time zero, for all species the regressions of growth on days at liberty were forced through the origin. As the variable 'days at liberty' was not under the control of the investigator, Model 2 regression was appropriate (Sokal \& Rohlf 1981, p. 459). Thus, the reduced major axis (geometric mean) regression coefficient ( $\left.b^{\prime}\right)$ and its standard error were calculated (Sokal \& Rohlf 1981, p. 550) and used to calculate growth rates in preference to the simple least squares linear regression coefficient. Before calculating the regression equations, any outlying points (externally studentized residuals $>2$ ) or extremely influential points (leverage $>2 \mathrm{p} / \mathrm{n}$, where $\mathrm{p}=$ number of explanatory variables and $n=$ sample size) (Belsley et al. 1980) were omitted from the analyses.

Otolith aging. During this study, the sagittae of 92 Epinephelus coioides, 174 E. Malabaricus, 298 Lutjanus argentimaculatus, and 423 L. russelli were used for age determination.

All otolith reading was conducted on sectioned sagittae. Right or left otoliths were selected at random for processing. Sectioning and counting were carried out as described by Ferreira \& Russ (1992).

To determine if the opaque bands were annual marks, tetracycline marking of otoliths of tagged fishes of all species was carried out at Alligator Creek (approx. $19^{\circ} 20^{\prime} \mathrm{S}, 146^{\circ} 55^{\prime} \mathrm{E}$ ) between January 1991 and March 1994. The fish were collected while fish trapping or caught on hook and line. Selecting only fish greater than $120 \mathrm{~mm}$ FL, 310 Epinephelus coioides, 219 E. malabaricus, 193 Lutjanus argentimaculatus, and $560 \mathrm{~L}$. russelli were marked with T-bar anchor tags, injected with oxytetracycline (dosage of $50 \mathrm{mg}$ $\mathrm{kg}^{-1}$ of body weight) into the coelomic cavity, and released. Recaptured, tetracycline-marked fish were processed and their otoliths prepared as described above for non-marked fish. The sectioned sagittae from these fish were observed microscopically under white light, ultraviolet light (UV) and a combination of both.

\section{RESULTS}

\section{Comparison of size structures (estuary/offshore)}

It was assumed that for all 4 species, the samples collected included fish of the largest sizes usually encountered in estuaries in the study area. It was clear from conversations with anglers that most tended to donate fish when they caught what they considered to be a large fish of that species. Thus, it is likely that few fish larger than those collected were caught from estuaries and not reported.

Samples were much more difficult to obtain from offshore areas than from estuaries. This is reflected in small offshore sample sizes (Table 1). Despite the small offshore samples for Epinephelus coioides, E. malabaricus and Lutjanus russelli, fishes of considerably larger sizes were trapped from offshore waters than from estuaries using the same fish traps. Apparently, if larger fishes of these species were available in these estuaries, they could have been trapped. Thus, given the spatially and temporally extensive trapping undertaken in estuaries during this study, it seems likely that the maximum sizes trapped reflected the normal maximum sizes of these species inhabiting estuaries of tropical northeastern Australia. This is supported by the fact that no E. coioides, E. malabaricus or L. russelli larger than those trapped were obtained from anglers fishing in the estuaries where trapping was carried out. Furthermore, for these species, only 1 individual larger than the largest trapped was obtained from any estuary within the study area. This was a line caught $L$. russelli (232 $\mathrm{mm}$ FL) which was slightly larger than the largest trapped (220 $\mathrm{mm}$ FL). During the study, $L$. argentimaculatus were only trapped occasionally in estuaries and not at all in offshore waters. However the maximum size recorded for line caught fish from estuaries was substantially smaller than the maximum size from offshore (Table 1). 


\section{Reproductive status}

Except for Lutjanus russelli in April, fishes of each species were collected from estuaries for gonad examination in all months (Table 2). Compared to fishes from offshore, the gonads of fishes of all 4 species from estuaries were small relative to body weight (Table 3 , Fig. 2).

Table 1. Size ranges of Epinephelus coioides, E. Malabaricus, Lutjanus argentimaculatus and $L$. russelli caught in Antillean- $Z$ fish traps, and supplied by anglers

\begin{tabular}{|c|c|c|c|c|}
\hline & $\begin{array}{r}\text { Estuary } \\
\text { FL range }(\mathrm{mm})\end{array}$ & $\mathrm{n}$ & $\begin{array}{l}\text { Offshore } \\
\text { FL range (mm) }\end{array}$ & e \\
\hline \multicolumn{5}{|l|}{ E. coioides } \\
\hline Trap & $120-500$ & 280 & $443-915$ & 8 \\
\hline Angler collection & $171-386$ & 72 & $645-1085$ & 7 \\
\hline \multicolumn{5}{|l|}{ E. malabaricus } \\
\hline Trap & $122-619$ & 334 & $582-762$ & 5 \\
\hline Angler collection & $180-515$ & 153 & $523-1199$ & 5 \\
\hline \multicolumn{5}{|c|}{ L. argentimaculatus } \\
\hline Trap & $71-212$ & 5 & - & - \\
\hline Angler collection & $147-541$ & 301 & $412-890$ & 26 \\
\hline \multicolumn{5}{|l|}{ L. russelli } \\
\hline Trap & $28-220$ & 2223 & $99-321$ & 30 \\
\hline Angler collection & $130-232$ & 154 & $189-445$ & 202 \\
\hline
\end{tabular}

For all species, a number of fishes had gonads too small to enable confident macroscopic sex determination (Table 3). Of the fish from estuaries that could be sexed, all Epinephelus spp. were identified as females, while for Lutjanus spp. both females and males were collected in similar numbers. Histological examination of the larger gonads from estuary samples supported the results of macroscopic examination (Table 4). All Epinephelus spp. with gonads sufficiently developed to allow sex determination were females, while for Lutjanus spp. both females and males were identified.

The ovaries of all female fish from estuaries were thin [max. diameter: $7 \mathrm{~mm}$ Lutjanus argentimaculatus $(540 \mathrm{~mm}$ FL); $3 \mathrm{~mm} L$. russelli (228 mm FL), Epinephelus coioides (471 $\mathrm{mm} \mathrm{FL)} \mathrm{and} \mathrm{E.} \mathrm{malabaricus}(595 \mathrm{~mm}$ FL)] and less than $1 / 4$ the length of the body cavity. No oocytes were visible to the naked eye. For all species from estuaries, histological examination showed the most advanced oocytes to be chromatin nucleolar stage (Stage 1) or perinucleolar stage (Stage 2), even during months when reproductively active fish were present offshore (Fig. 2). Neither $\alpha$ or $\beta$ stage atretic structures (Hunter

Table 2. Summary of Epinephelus spp. and Lutjanus spp. collected for sex status determination

\begin{tabular}{|c|c|c|c|c|c|c|c|c|c|}
\hline \multirow[t]{2}{*}{ Month } & \multirow[t]{2}{*}{ Location } & \multicolumn{2}{|c|}{ E. coioides } & \multicolumn{2}{|c|}{ E. malabaricus } & \multicolumn{2}{|c|}{ L. argentimaculatus } & \multicolumn{2}{|c|}{ L. russelli } \\
\hline & & Max. FL $(\mathrm{mm})$ & $\mathrm{n}$ & Max. FL (mm) & $\mathrm{n}$ & Max. FL (mm) & $\mathrm{n}$ & $\operatorname{Max} . F L(m m)$ & $\mathrm{n}$ \\
\hline January & $\begin{array}{l}\text { Estuary } \\
\text { Offshore }\end{array}$ & $\begin{array}{l}262 \\
780\end{array}$ & $\begin{array}{r}16 \\
3\end{array}$ & $\begin{array}{c}433 \\
-\end{array}$ & $\begin{array}{c}27 \\
-\end{array}$ & $\begin{array}{l}490 \\
592\end{array}$ & $\begin{array}{r}25 \\
5\end{array}$ & $\begin{array}{l}200 \\
337\end{array}$ & $\begin{array}{r}23 \\
1\end{array}$ \\
\hline February & $\begin{array}{l}\text { Estuary } \\
\text { Offshore }\end{array}$ & $\begin{array}{l}384 \\
915\end{array}$ & $\begin{array}{r}14 \\
3\end{array}$ & $\begin{array}{c}544 \\
-\end{array}$ & $\begin{array}{c}21 \\
-\end{array}$ & $\begin{array}{c}475 \\
-\end{array}$ & $\begin{array}{l}23 \\
-\end{array}$ & $\begin{array}{l}183 \\
382\end{array}$ & $\begin{array}{l}17 \\
23\end{array}$ \\
\hline March & $\begin{array}{l}\text { Estuary } \\
\text { Offshore }\end{array}$ & $\begin{array}{l}377 \\
645\end{array}$ & $\begin{array}{r}11 \\
1\end{array}$ & $\begin{array}{c}498 \\
-\end{array}$ & $\begin{array}{l}12 \\
-\end{array}$ & $\begin{array}{c}466 \\
-\end{array}$ & $\begin{array}{c}39 \\
-\end{array}$ & $\begin{array}{l}136 \\
365\end{array}$ & $\begin{array}{r}9 \\
20\end{array}$ \\
\hline April & $\begin{array}{l}\text { Estuary } \\
\text { Offshore }\end{array}$ & $\begin{array}{l}387 \\
436\end{array}$ & $\begin{array}{l}9 \\
2\end{array}$ & $\begin{array}{c}545 \\
-\end{array}$ & $\begin{array}{l}11 \\
-\end{array}$ & $\begin{array}{l}411 \\
445\end{array}$ & $\begin{array}{l}12 \\
31\end{array}$ & - & - \\
\hline May & $\begin{array}{l}\text { Estuary } \\
\text { Offshore }\end{array}$ & $\begin{array}{c}405 \\
-\end{array}$ & $\begin{array}{l}18 \\
-\end{array}$ & $\begin{array}{l}525 \\
687\end{array}$ & $\begin{array}{r}13 \\
2\end{array}$ & $\begin{array}{l}422 \\
636\end{array}$ & $\begin{array}{r}16 \\
5\end{array}$ & $\begin{array}{l}159 \\
362\end{array}$ & $\begin{array}{l}16 \\
37\end{array}$ \\
\hline June & $\begin{array}{l}\text { Estuary } \\
\text { Offshore }\end{array}$ & $\begin{array}{c}471 \\
1085\end{array}$ & $\begin{array}{r}10 \\
1\end{array}$ & $\begin{array}{c}400 \\
-\end{array}$ & $\begin{array}{c}13 \\
-\end{array}$ & $\begin{array}{l}482 \\
615\end{array}$ & $\begin{array}{r}29 \\
1\end{array}$ & $\begin{array}{l}228 \\
296\end{array}$ & $\begin{array}{l}23 \\
10\end{array}$ \\
\hline July & $\begin{array}{l}\text { Estuary } \\
\text { Offshore }\end{array}$ & $\begin{array}{c}315 \\
-\end{array}$ & $\begin{array}{l}8 \\
-\end{array}$ & $\begin{array}{c}433 \\
-\end{array}$ & $\begin{array}{l}12 \\
-\end{array}$ & $\begin{array}{l}410 \\
476\end{array}$ & $\begin{array}{r}17 \\
2\end{array}$ & $\begin{array}{l}230 \\
298\end{array}$ & $\begin{array}{l}27 \\
23\end{array}$ \\
\hline August & $\begin{array}{l}\text { Estuary } \\
\text { Offshore }\end{array}$ & $\begin{array}{c}333 \\
-\end{array}$ & $\begin{array}{l}11 \\
-\end{array}$ & $\begin{array}{c}595 \\
-\end{array}$ & $\begin{array}{l}16 \\
-\end{array}$ & $\begin{array}{c}288 \\
-\end{array}$ & $\begin{array}{l}11 \\
-\end{array}$ & $\begin{array}{l}158 \\
360\end{array}$ & $\begin{array}{r}14 \\
5\end{array}$ \\
\hline September & $\begin{array}{l}\text { Estuary } \\
\text { Offshore }\end{array}$ & $\begin{array}{c}387 \\
-\end{array}$ & $\begin{array}{l}18 \\
-\end{array}$ & $\begin{array}{c}422 \\
-\end{array}$ & $\begin{array}{c}18 \\
-\end{array}$ & $\begin{array}{c}540 \\
-\end{array}$ & $\begin{array}{l}31 \\
-\end{array}$ & $\begin{array}{l}232 \\
309\end{array}$ & $\begin{array}{l}18 \\
27\end{array}$ \\
\hline October & $\begin{array}{l}\text { Estuary } \\
\text { Offshore }\end{array}$ & $\begin{array}{c}394 \\
-\end{array}$ & $\begin{array}{l}13 \\
-\end{array}$ & $\begin{array}{c}594 \\
-\end{array}$ & $\begin{array}{c}26 \\
-\end{array}$ & $\begin{array}{l}541 \\
654\end{array}$ & $\begin{array}{r}44 \\
7\end{array}$ & $\begin{array}{l}204 \\
405\end{array}$ & $\begin{array}{l}23 \\
13\end{array}$ \\
\hline November & $\begin{array}{l}\text { Estuary } \\
\text { Offshore }\end{array}$ & $\begin{array}{c}368 \\
-\end{array}$ & $\begin{array}{l}17 \\
-\end{array}$ & $\begin{array}{l}499 \\
523\end{array}$ & $\begin{array}{r}20 \\
3\end{array}$ & $\begin{array}{l}487 \\
890\end{array}$ & $\begin{array}{r}28 \\
4\end{array}$ & $\begin{array}{l}209 \\
329\end{array}$ & $\begin{array}{l}38 \\
28\end{array}$ \\
\hline December & $\begin{array}{l}\text { Estuary } \\
\text { Offshore }\end{array}$ & $\begin{array}{c}420 \\
-\end{array}$ & 11. & $\begin{array}{c}562 \\
-\end{array}$ & $\begin{array}{c}19 \\
-\end{array}$ & $\begin{array}{l}450 \\
528\end{array}$ & $\begin{array}{r}23 \\
1\end{array}$ & $\begin{array}{l}205 \\
410\end{array}$ & $\begin{array}{r}21 \\
8\end{array}$ \\
\hline
\end{tabular}


Table 3. Summary of sexes and gonad sizes of Epinephelus spp. and Lutjanus spp. determined by macroscopic examination. The numbers of fish and the maximum proportion of body weight contributed by the female or male gonad are shown. Ind.. sex indeterminate

\begin{tabular}{|c|c|c|c|c|c|}
\hline \multirow{2}{*}{\multicolumn{2}{|c|}{ Species }} & \multirow{2}{*}{\multicolumn{2}{|c|}{ Estuary }} & \multirow{2}{*}{\multicolumn{2}{|c|}{ Offshore }} \\
\hline & & & & & \\
\hline \multirow[t]{3}{*}{ E. coioides } & $\varphi$ & 144 & 2.7 & 7 & 8.3 \\
\hline & $0^{4}$ & - & - & 3 & 7.9 \\
\hline & Ind. & 12 & - & & - \\
\hline \multirow[t]{3}{*}{ E. malabaricus } & ९ & 185 & 8.9 & - & -. \\
\hline & $0^{\prime \prime}$ & - & - & 3 & 6.8 \\
\hline & Ind. & 23 & - & 2 & 5.0 \\
\hline \multirow[t]{3}{*}{ L. argentimaculatus } & १ & 141 & 21.2 & 12 & 178.0 \\
\hline & $\sigma^{\prime \prime}$ & 132 & 9.0 & 13 & 27.5 \\
\hline & Ind. & 25 & - & - & - \\
\hline \multirow[t]{3}{*}{ L. russelli } & & 53 & 22.4 & 108 & 406.0 \\
\hline & $\sigma^{7}$ & 55 & 7.5 & 114 & 40.3 \\
\hline & Ind. & 121 & - & 4 & - \\
\hline
\end{tabular}

\& Macewicz 1985, Hunter et al. 1986 , Kjesbu \& Klungsoyr 1991) were found in the ovaries of any fish from estuarjes. Thus, on the basis of gonad size and of macroscopic and histological examination of ovaries, all female fishes of all 4 species from estuaries were classified as reproductively immature.

The testes of all male Lutjanus argentimaculatus and $L$. russelli from estuaries were firm, narrow and strap-like, and comprised only a small proportion of body weight (Table 3). The most advanced spermatic tissue present in most $L$. argentimaculatus and $L$. russelli testes from estuaries were primary and secondary spermatocytes. However, as well as containing large areas of immature spermatic tissue, the testes of a sample of 3 male L. argentimaculatus (432 to $541 \mathrm{~mm}$ ) collected from the mouth of Ross Creek (Fig. 1) in October 1993 contained some spermatids and spermatozoa. In these fish, the spermatids and spermatozod were confined to the proximal (posterior) parts of the testes. As the testes of these males were very small and the area of reproductive development limited, it was assumed that they represented fish in early stages of reproductive maturity. Four large female $L$. argentimaculatus sampled at the same time were all reproductively immature. This included the largest female L. argentimaculatus $(540 \mathrm{~mm})$ obtained from estuaries during the study.

Table 4. Summary of results of histological examination of gonads of Epinephelus spp. and Lutjanus spp. collected from estuary and offshore waters. Ind.: sex indeterminate

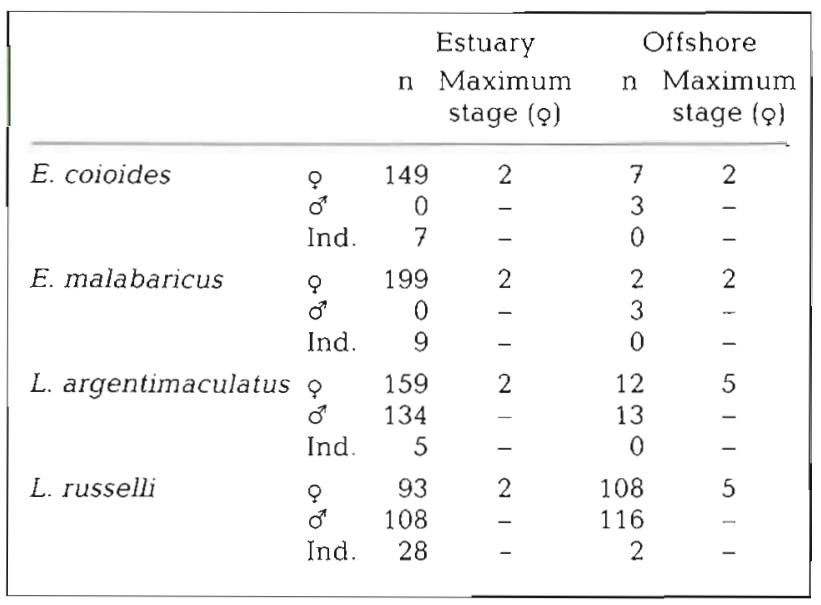

Fig. 2. Changes in relative gonad size and stage over time for Lutjanus russelli from $(0, \square)$ estuaries and $(\boldsymbol{Q}, \boldsymbol{\square})$ offshore waters. Data presented are maxima of (a) gonad weight as a proportion of cleaned weight and (b) maximum gonad stage for each month 
Table 5. Summary of tagging and recapture data showing numbers of fish tagged and recaptured, the maximum days at liberty (DAL), and maximum growth between recaptures

\begin{tabular}{|lrcrr|}
\hline Species & $\begin{array}{c}\text { No. } \\
\text { tagged }\end{array}$ & $\begin{array}{c}\text { No. } \\
\text { recaptured }\end{array}$ & $\begin{array}{c}\text { Max. } \\
\text { DAL }\end{array}$ & $\begin{array}{c}\text { Max. } \\
\text { growth }\end{array}$ \\
\hline Epinephelus coioides & 398 & 104 & 619 & 129 \\
Epinephelus malabaricus & 293 & 63 & 728 & 202 \\
Lutjanus argentimaculatus & 120 & 10 & 395 & 66 \\
Lutjanus russelli & 1070 & 43 & 238 & 44 \\
\hline
\end{tabular}

\section{Otolith aging}

Of the tetracycline-marked fish, 4 Epinephelus coioides, 5 E. malabaricus, 2 Lutjanus argentimaculatus and $1 L$. russelli had been at liberty for more than a year. In each case, sectioned sagittae of the tetracycline-marked fish showed a single opaque band outside of the fluorescent tetracycline mark, indicating that the opaque bands did indeed represent an annulus.

Further evidence that the opaque bands represented annuli came from growth rates from

Table 6. Summary of the correlation between growth rate (size increment per unit of time) and mean fork length (for the increment in question) for Epinephelus spp. and Lutjanus spp.

\begin{tabular}{lrrrc|} 
Species & $\mathrm{r}$ & $\mathrm{n}$ & $\mathrm{p}$ \\
\hline Epinephelus coioides & -0.1018 & 104 & 0.3036 \\
Epinephelus malabaricus & -0.0189 & 63 & 0.3957 \\
Lutjanus argentimaculatus & -0.4478 & 10 & 0.1944 \\
Lutjanus russelli & 0.0448 & 43 & 0.7754 \\
\hline
\end{tabular}

Table 7. Summary of the regression between growth rate and days at liberty for Epinephelus spp. and Lutjanus spp. For each species the reduced major axis (geometric mean) regression coefficient $\left(b^{\prime}\right)$ and its standard error are presented together with the coefficient of determination $\left(\mathrm{r}^{2}\right)$

\begin{tabular}{lcccr|}
\hline Species & $b^{\prime}$ & SE & $\mathrm{r}^{2}$ & $\mathrm{df}$ \\
\hline Epinephelus coioides & 0.2253 & 0.0072 & 0.9042 & 95 \\
Epinephelus malabaricus & 0.2565 & 0.0100 & 0.9070 & 61 \\
Lutjanus argentimaculatus & 0.1780 & 0.0074 & 0.9896 & 5 \\
Lutjanus russelli & 0.1911 & 0.0107 & 0.8783 & 38 \\
\hline
\end{tabular}

\section{Growth from mark-recapture}

Capture and recapture data for Epinephelus coioides, E. malabaricus, Lutjanus argentimaculatus and $L$. russelli from estuaries are summarised in Table 5. For each of the 4 species, growth rate (size increment per unit of time) and mean fork length were not significantly correlated (Table 6). Thus, for all species, the growth rate for estuary fishes was independent of fork length over the size ranges sampled.

For all 4 species, there was a strong linear relationship between growth and period at liberty (Table 7 ). For Epinephelus coioides ( $\mathrm{n}=104)$, interpolation suggested a growth rate of approximately $82 \mathrm{~mm} \mathrm{yr}^{-1}$, for E. malabaricus ( $\mathrm{n}=63$ ), approximately $94 \mathrm{~mm} \mathrm{yr}^{-1}$, for Lutjanus argentimaculatus ( $\mathrm{n}=10$ ), approximately $65 \mathrm{~mm} \mathrm{yr}^{-1}$, and for $L$. russelli $(\mathrm{n}=43$ ), approximately $70 \mathrm{~mm} \mathrm{yr}^{-1}$. mark-recapture. For each species, when a regression line derived from growth from mark-recapture data and centred on the mean size and count from otolith data was plotted with the otolith count data, the growth rate (slope) from mark-recapture corresponded well with the growth between age classes from otolith aging (Figs, $3 \& 4$ )

\section{Estuary samples}

For each species, there was a broad variation in sizes at each count; however, there was a general trend for the number of annuli to increase with increasing fish size. From estuary samples, Epinephelus coioides ( $n=87$ ) displayed between 1 and 5 annual rings (Fig. 3a); E. malabaricus $(n=171)$, between 0 and 7 rings (Fig 3b); Lutjanus argentimaculatus ( $\mathrm{n}=276$ ), between 0 and 8 rings (Fig. $4 \mathrm{a})_{i}$ and L. russelli ( $\mathrm{n}=$ 196), between 0 and 2 rings (Fig. 4 b).

\section{Offshore samples}

Few samples of Epinephelus coioides $(n=5)$ or $E$. malabaricus $(\mathrm{n}=3$ ) were available from of fshore. However, for each species the largest individual from offshore displayed more rings (E. coioides, 16; E. malabaricus, 8) than did the largest estuary fish (Fig. 3a, b). Lutjanus argentimaculatus $(n=22)$ displayed up to 32 annuli, with growth appearing to slow in older fish (Fig. 4a). L. russelli, with an extensive offshore sample $(n=227$ ), showed a maximum of approximately 17 annual rings with growth appearing to slow after approximately 3 yr (Fig. 4b). For L argentimaculatus, and particularly L. russelli, growth appearsed to slow shortly after the transition from estuarine to offshore habitats.

\section{DISCUSSION}

The size, age, growth and reproductive data presented here strongly suggest that the estuary popula- 

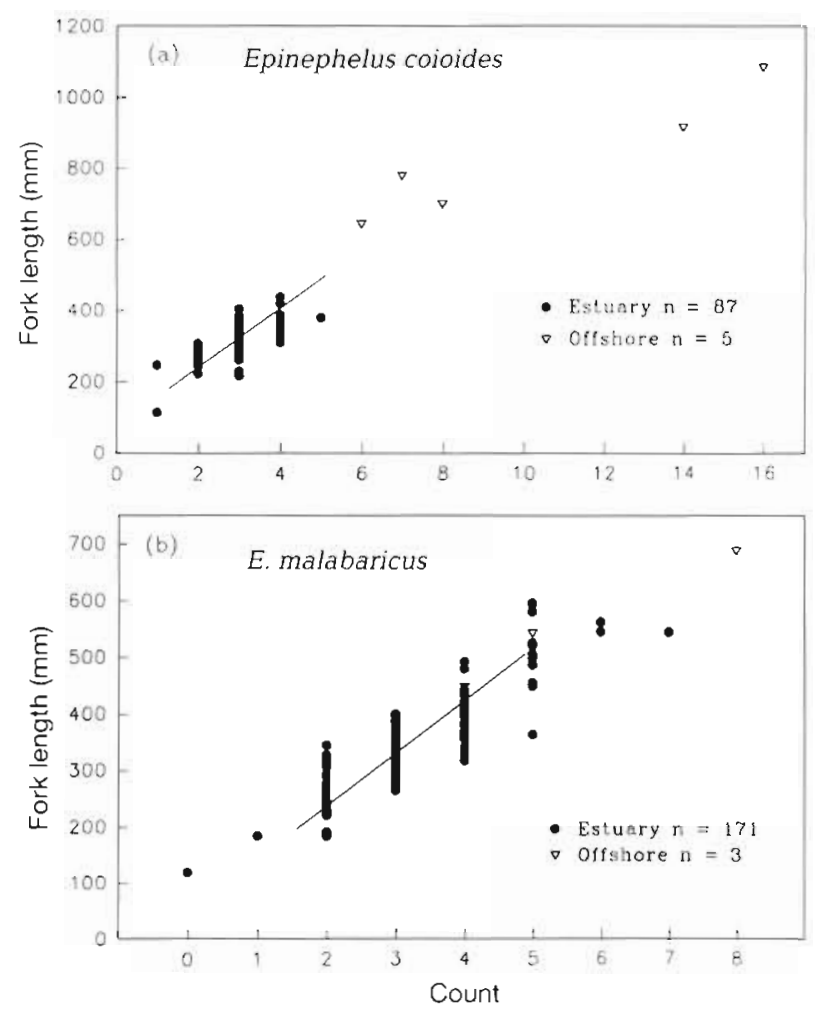

Fig. 3. Relationship between fork length and sagittal otolith counts for (a) Epinephelus coioides and (b) E. malabaricus. Line represents the growth from mark-recapture data. (•) Fish from estuaries, $(\nabla)$ fish from of fshore

tions of Epinephelus coioides, E. Malabaricus, Lutjanus argentimaculatus and $L$. russelli studied were comprised of juveniles.

\section{Size, age and growth}

Even though fish trapping in estuaries in tropical north Queensland was extensive, both spatially and temporally, the maximum sizes of Epinephelus coioides, E. malabaricus and Lutjanus russelli trapped were considerably smaller than the largest sizes captured in the same traps from offshore waters. Similarly, collections from anglers fishing in estuaries produced relatively small individuals compared to fish collected from offshore. While $L$. argentimaculatus trapped poorly, considerable numbers of specimens were collected by angling or were donated by anglers. All the fish comprising these samples were relatively small compared to fish obtained from offshore waters. As $L$. argentimaculatus is an important recreational sportfish in North Queensland estuaries, and close contact was kept with local fishing clubs, it seems likely that few if any larger $L$. argentimaculatus were caught and not reported. The largest $E$ coioides
(387 mm FL; Sheaves 1992), E. malabaricus $(440 \mathrm{~mm}$

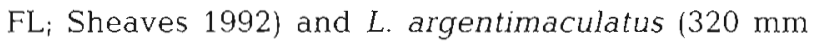
standard length, SL; Blaber et al. 1989) previously reported from estuaries in tropical Australia are all smaller than the largest fish from estuaries in this study. The largest L. russelli $(237 \mathrm{~mm}$ FL; Sheaves 1992) previously reported from Australian estuaries was of similar size to the largest individual captured during the present study (232 $\mathrm{mm} \mathrm{FL).}$

While many studies in both estuarine and offshore habitats in the tropical Indo-Pacific have reported at least one of these species, sample sizes have generally been small and fish sizes rarely quoted. Where sizes are available for Lutjanus argentimaculatus and L. russelli (Blaber et al. 1989) the same pattern as in the present study is seen: larger sizes from offshore locations than from estuaries.

There is some anecdotal evidence from the recreational fishing sector of large Epinephelus spp. occurring in estuaries in tropical northeastern Queensland. However, the discrepancy between the maximum sizes trapped in estuaries and the maximum sizes able to be caught in the same traps in offshore waters suggests that if larger fish were common in estuaries they would
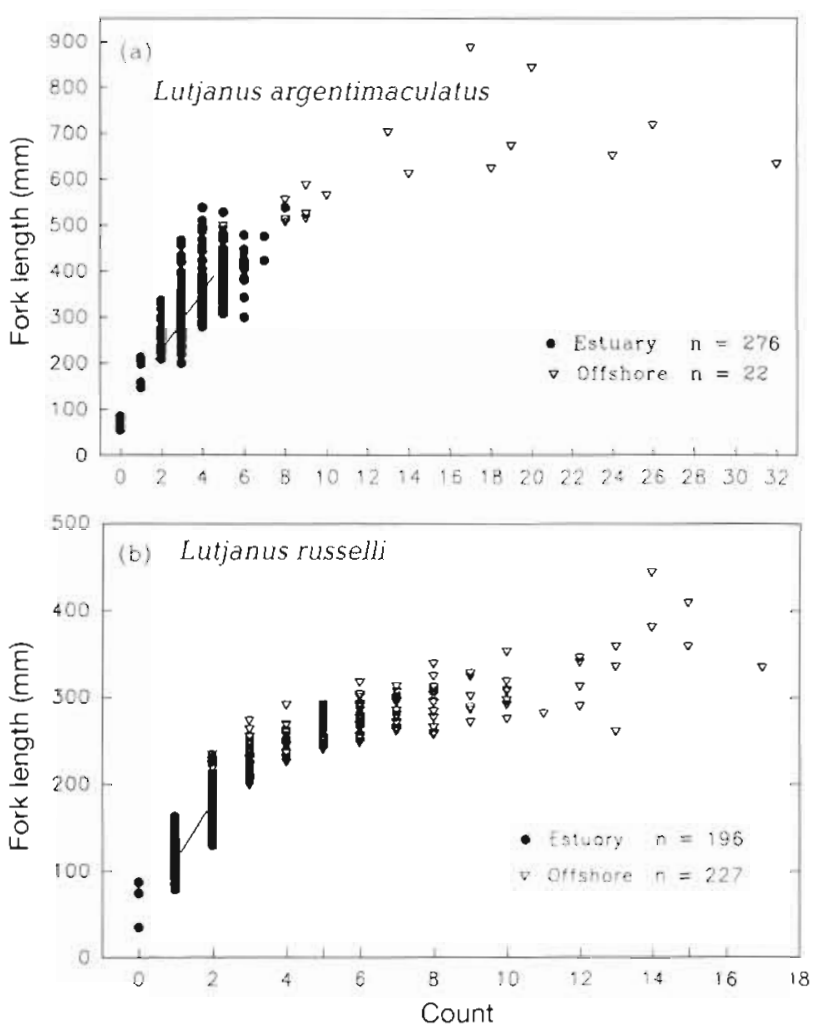

Fig. 4. Relationship between fork length and sagittal otolith counts for (a) Lutjanus argentimaculatus and (b) L. russelli. Line represents the growth from mark-recapture data. (•) Fish from estuaries, ( $\nabla)$ fish from offshore 
have been captured. It appears that if large Epinephelus spp. do occur in estuaries, they probably constitute only a minor part of the main estuary population.

From the otolith data it seems that the maximum period spent in estuaries was about $5 \mathrm{yr}$ for Epinephelus coioides, 7 yr for E. Malabaricus, 8 yr for Lutjanus argentimaculatus and 2 yr for $L$. russelli. The exact period of residency of these species in estuaries is difficult to determine. The process of reading sectioned otoliths is subjective (Campana \& Neilson 1985 , Thresher 1988, Talbot \& Doyle 1992), particularly for young fish, as it is difficult to determine exactly what period of time has elapsed prior to the deposition of the first annulus. While the counting of daily rings may overcome this, a second problem remains. The aging of fish from an estuary only tells the age of fish still resident within the estuary. Unless fish can be sampled immediately on exiting an estuary and it can be demonstrated clearly that those fish have originated from that estuary, it is impossible to determine the range of ages at which fish actually migrate from estuaries.

For each of the 4 species studied here, maximum ages determined for fish from estuaries were considerably younger than those for fish from offshore waters. Additionally, for each species the size at age determined from sectioned otoliths agreed well with the growth data from mark-recapture. Furthermore, as the growth of fish is expected to follow a curvilinear trajectory, with reduced growth at larger sizes (Pauly 1984), the Iinear growth of all 4 species in estuaries, implied by the mark-recapture data, is consistent with rapid growth in the rising part of an asymptotic growth curve. This suggests that the fish from estuaries were sampled over a restricted section of the lower part of the growth curve only.

\section{Reproductive status}

All female Lutjanus argentimaculatus, L. russelli, Epinephelus coioides and E. malabaricus collected from estuaries were found to be reproductively immature. No reproductively active individuals were found. This included periods when reproductively active females were present in samples from offshore. As the juvenile period lasts until maturation of the first gametes (Balon 1984), all the female fish sampled from estuaries can be considered juveniles. Although a sample of 3 male L. argentimaculatus from one estuary showed some degree of reproductive maturity, it is assumed that these were fishes in the early stages of reproductive development only. The testes of these males were very small, and mature spermatic tissue was limited to proximal regions of the gonads. Further- more, 4 large females sampled at the same time showed no sign of reproductive development, suggesting that the spermatic development was not related to spawning at that time. It is possible that these were a group of large fish preparing to migrate from the estuary. Of the E. coioides and E. malabaricus possessing gonads advanced enough for sex determination, all individuals of both species were found to be females. As Epinephelus spp. are recognised as protogynous hermaphrodites (Bannerot et al. 1987, Rándall et al. 1990) the presence of only non-reproductive females with poorly developed gonads suggests that the populations consisted of pre-reproductive individuals. Taken together, the data presented here strongly suggest that $L$. argentimaculatus, $L$. russelli, $E$. coioides and E. malabaricus do not become reproductively active within the estuaries studied. This implies that the estuarine populations of these species consist of juveniles. This is comparable with the situation in South Africa, where a large number of fish species use estuaries as juvenile habitats but return to the sea before attaining sexual maturity (Blaber \& Cyrus 1983, Cyrus \& Blaber 1984, Whitfield 1990). Similarly, in Florida, USA, juvenile Sciaenops ocellatus are found in estuaries but adults spawn in nearshore waters (Peters \& McMichael 1987), and juvenile Lutjanus griseus are found in mangrove areas although adults spawn on offshore reefs (Starck \& Schroeder 1970).

\section{Estuaries as juvenile habitats for lutjanid and serranid fishes}

Most previous studies have classified Lutjanus russelli from the tropical Indo-Pacific estuaries as juveniles (Allen 1985, Allen \& Talbot 1985, Blaber et al. 1985, Blaber 1986, Blaber \& Milton 1990, Thollot et al. 1990). The results of the present study agree with this classification. Where life-history stages have been recorded, previous studies (Shine et al. 1973, Blaber 1980, Blaber et al, 1985, Blaber \& Milton 1990, Thollot et al. 1990) have classified estuary populations of Epinephelus coioides, E. malabaricus and L. argentimaculatus in the Indo-Pacific as being comprised of both juveniles and adults. The present study does not support this. Despite extensive collections, no female fish of any of the 3 species collected from estuaries possessed mature gonads. Along with the fact that fish collected from estuaries during this study were smaller and younger than those from offshore, this indicates that the populations of these species within the estuaries studied probably contain few adults, if any. However, it should be noted that as there are infrequent reports of anglers sighting large (>1 m) groupers in estuaries in northeastern Australia, it is possible that 
large E. coioides or E. malabaricus may occasionally be found in the estuaries studied.

The pre-reproductive statuses of Lutjanus argentimaculatus, L. russelli, Epinephelus coioides and $E$. malabaricus in the estuaries studied implies that they move offshore to spawn. The lack of large, old, reproductively active individuals suggests that adults of these species generally do not return to estuaries. In South Africa, 3 species of Gerres that leave estuarine juvenile habitats to spawn offshore do not usually return to estuaries (Cyrus \& Blaber 1984). This is the case for most fish in South Africa that spawn offshore but use estuaries as juvenile habitats (Day et al. 1981). Previous workers have asserted that $L$. argentimaculatus (Johannes 1978, Thollot et al. 1990), E. malabaricus and L. russelli (Thollot et al. 1990) migrate offshore. Other studies have suggested that $L$. argentimaculatus and L. russelli (Allen 1985, Allen \& Talbot 1985, Randall et al. 1990) occur as juveniles in estuaries and adults in offshore habitats, inferring migration away from the estuaries. Despite the necessity of a spawning migration for these fishes, few offshore movements have been documented for any of these species. One L. argentimaculatus tagged during a sportfish tagging program moved from an estuary on Hinchinbrook Island (Fig. 1) to a reef about $80 \mathrm{~km}$ to the northeast (ANSA 1991). An E. malabaricus tagged during the present study (length at release $480 \mathrm{~mm}$ FL) also moved offshore. It was tagged in Barramundi Creek (Fig. 1) and captured by an angler 17 mo later on Lodestone Reef, some $75 \mathrm{~km}$ to the north. The paucity of direct evidence of movement from estuaries to offshore habitats needs to be rectified. It may be that, while recapture rates are reasonably high within the estuaries where the fish are tagged, when tagged fish move out of estuaries, they mix with fish from other estuaries and spread out over large areas of of fshore reef water, resulting in low probabilities of recapture. If so, a substantial tagging and recapture effort would be required to demonstrate movement offshore.

These species either can't or don't spawn in estuaries. However, the reasons why they migrate offshore and the cues that initiate migration are unknown. There are many possible reasons for spawning offshore rather than in estuaries. Perhaps the sperm or ova of these species are not viable in the extreme physical conditions prevalent in estuaries. Alternatively, an offshore migration may represent a mechanism for increasing genetic mixing. This could occur in 2 ways. Fish migrating offshore would be likely to breed with fish from other estuaries, and, after a planktonic larval stage followed by an offshore spawning migration, the offspring they produced would be unlikely to return to the location where they were spawned.
Estuaries are not the only habitats where juvenile Lutjanus russelli and $L$, argentimaculatus are found. Small $L$. russelli have been reported in small numbers from coastal seagrass beds (Blaber et al. 1992, Coles et al. 1993). Other studies of coastal seagrass beds (Robertson \& Duke 1987) in tropical northern Australia failed to produce any L. russelli or L. argentimaculatus. As juvenile $L$. argentimaculatus and $L$. russelli have been reported from offshore habitats only sporadically and in low numbers, the importance of these areas as juvenile habitats is unclear. It is uncertain if juvenile Epinephelus coioides or E. Malabaricus occur in habitats other than estuaries. Studies that have reported these species from coastal or reef habitats (e.g. Blaber et al. 1994) have not clearly identified the life-history stages present. Notwithstanding the potential for alternative habitats to provide nursery grounds for these 4 species, the presence of large numbers of functionally juvenile E. coioides, E. malabaricus and L. russelli in trap catches during this study, along with the fact that all 4 species are common components of estuary angling catches (Sheaves pers. obs.), suggests that these species are common in estuaries of northeastern Australia. This implies that estuaries are important nursery areas for these species, probably supplying a large part of the adult population found in offshore waters.

Acknowledgements. I thank all those who assisted in this project with the supply of fish for dissection. My particular thanks go to all the anglers who supplied fish and to the members of the Australian Institute of Marine Science, Fish Biology unit who supplied many fish from offshore. I also extend special thanks to B. Molony, G. Russ and D. Williams for their invaluable advice and support during this project.

\section{LITERATURE CITED}

Allen GR (1985) Snappers of the world. FAO Species Catalogue, Vol 6. FAO, Rome

Allen GR, Talbot FH (1985) Review of the snappers of the genus Lutjanus (Pisces: Lutjanidae) from the Indo-Pacific, with the description of a new species. Indo-Pacific Fishes, Number 11. Bernice Pauahi Bishop Museum, Honolulu

ANSA (1991) Australian National Sportfishing Association Queensland, Sportfish Tagging Program, 1990/1991 Report. Australian National Sportfishing Association, Queensland, Brisbane

Balon EK (1984) Patterns in the evolution of reproductive styles in fishes. In: Potts GW, Wootton RJ (eds) Fish reproduction: strategies and tactics. Academic Press, London, p $35-53$

Bannerot S, Fox WW Jr, Powers JE (1987) Reproductive strategies and the management of snappers and groupers in the Gulf of Mexico and Caribbean. In: Polovina JJ, Ralston S (eds) Tropical snappers and groupers: biology and management. Westview Press, Boulder, p 561-603

Belsley DA, Kuh E, Welsch RE (1980) Regression diagnostics: identifying influential data and sources of collinearity. John Wiley and Sons, New York 
Blaber SJM (1980) Fish of the Trinity Inlet system of north Queensland with notes on the ecology of fish faunas of tropical Indo-Pacific estuaries. Aust J mar Freshwat Res $31: 137-146$

Blaber SJM (1986) Feeding selectivity of a guild of piscivorous fish in mangrove areas of north-west Australia. Aust $J$ mar Freshwat Res 37:337-345

Blaber SJM, Brewer DT, Harris AN (1994) Distribution, biomass and community structure of demersal fishes of the Gulf of Carpentaria, Australia. Aust $J$ mar Freshwat Res 45:375-396

Blaber SJM, Brewer DT, Salini JP (1989) Species composition and biomasses of fishes in different habitats of a tropical northern Australian estuary: their occurrence in the adjoining sea and estuarine dependence. Estuar coast Shelf Sci 29:509-531

Blaber SJM, Brewer DT, Salini JP, Kerr J, Conacher C (1992) Species composition and biomasses of fishes in tropical seagrasses at Groote Eylandt, northern Australia. Estuar coast Shelf Sci 35:605-620

Blaber SJM, Cyrus DP (1983) The biology of Carangidae (Teleostei) in natal estuaries. Aust J mar Freshwat Res 22: 173-188

Blaber SJM, Milton DA (1990) Species composition, community structure and zoogeography of fishes of mangrove estuaries in the Solomon Islands. Mar Biol 105:259-267

Blaber SJM, Young JW, Dunning MC (1985) Community structure and zoogeographic affinities of the coastal fishes of the Dampier region of north-western Australia. Aust $J$ mar Freshwat Res 36:247-266

Campana SE, Neilson JD (1985) Microstructure of fish otoliths. Can J Fish Aquat Sci 42:1014-1032

Coles RG, Lee Long WJ, Watson RA, Derbyshire KJ (1993) Distribution of seagrasses, and their fish and penaeid prawn communities, in Caurns Harbour, a tropical estuary, northern Queensland, Australia. Aust J mar Freshwat Res 44:193-210

Cyrus DP, Blaber SJM (1984) The reproductive biology of Gerres in natal estuaries. J Fish Biol 24:491-504

Day JH, Blaber SJM, Wallace JH (1981) Estuarine fishes. In: Day JH (ed) Estuarine ecology with particular reference to southern Africa. Balkema, Rotterdam, p 197-221

Ferreira BP, Russ GR (1992) Age, growth and mortality of the inshore coral trout Plectropomus maculatus (Pisces: Serranidae) from the central Great Barrier Reef, Australia. Aust J mar Freshwat Res 43:1301-1312

Hunter JR, Macewicz BJ (1985) Rates of atresia in the ovary of captive and wild northern anchovy, Engraulis mordax. Fish Bull US 83(2):119-136

Hunter JR, Macewicz BJ, Sibert JR (1986) The spawning frequency of skipjack tuna, Katsuwonus pelamis, from the South Pacific. Fish Bull US 84(4):895-903

Johannes RE (1978) Reproductive strategies of coastal marine fishes in the tropics. Environ Biol Fish 3(1):65-84

Kjesbu OS, Klungsoyr J (1991.) Fecundity, atresia, and egg size of captive Atlantic cod (Gadus morhua) in relation to proximate body composition. Can J Fish Aquat Sci 48:2333-2343

This article was presented by D. M. Alongi (Senior Editorial Advisor), Townsville, Australla
McCormick MI, Molony BW (1992) Effects of feeding history on the growth characteristics of a reef fish at settlement. Mar Biol 114:165-173

Pauly D (1984) Fish population dynamics in tropical waters: a manual for use with programmable calculators. ICLARM Studies and Reviews No. 8, Manila, p 23-40

Peters KM, McMichael RH Jr (1987) Early life history of the red drum, Sciaenops ocellatus (Pisces: Sciaenidae), in Tampa Bay, Florida. Estuaries 10:92-107

Randall JE (1987) A preliminary synopsis of the groupers (Perciformes: Serranidae: Epinephelinae) of the IndoPacific region. In: Polovina JJ, Rolston S (eds) Tropical snappers and groupers: biology and management. Westview Press, Boulder, p 89-188

Randall JE, Allen GR, Steene RC (1990) Fishes of the Great Barrier Reef and Coral Sea. Crawford House Press, Bathurst. p 89-184

Randall JE, Ben-Tuvia A (1983) A review of the groupers (Pisces: Serranidae: Epinephelinae) of the Red Sea, with description of a new species of Cephalopholi. Bull mar Sci 33(2):373-426

Robertson AI, Duke NC (1987) Mangroves as nursery sites comparisons of the abundance and species composition of fish and crustaceans in mangroves and other nearshore habitats in tropical Australia. Mar Biol 96:193-205

Sheaves MJ (1992) Patterns of distribution and abundance of fishes in different habitats of a mangrove-lined tropical estuary, as determined by fish trapping. Aust $\mathrm{J}$ mar Freshwat Res 43(6): 1461-1479

Sheaves MJ (1993) Patterns of movement of some fishes within an estuary in tropical Australia. Aust J mar Freshwat Res $44: 867-880$

Sheaves MJ (1.995) Effect of design modifications and soak time variations on Antillean- $Z$ fish trap performance in a tropical estuary. Bull mar Sci 56\{2\}:475-489

Shine R, Ellway CP, Hegerl EJ (1973) A biological survey of the Tallebudgera Creek estuary. Operculum 3(5-6): $59-83$

Sokal RR, Rohlf FJ (1981) Biometry, 2nd edn. Freeman, New York

Starck WA II, Schroeder RE (1970) Investigations on the gray snapper, Lutjanus griseus. University of Miami Press, Coral Gables

Talbot AJ, Doyle RW (1992) Statistical interrelation of length, growth, and scale circulus spacing: use of ossification to detect nongrowing fish. Can J Fish Aquat Sci 49:701-707

Thollot P, Kulbicki M, Wantiez L (1990) Temporal patterns of fish populations in three habitats of the St. Vincent Bay area (New Caledonia): coral reefs, soft bottoms and mangroves. Proceedings ISRS Congress, Noumea 1990:127-1.36

Thresher RE (1988) Otolith microstructure and the dernography of coral reef fishes. TREE 3(3):78-80

West G (1990) Methods of assessing ovarian development in fishes: a review. Aust J mar Freshwat Res 41:199-222

Whatfield AK (1990) Life-history styles of fishes in South African estuaries. Environ Biol Fish 28:295-308

Manuscript first received: February 8, 1995

Revised version accepted: July 21, 1995 